\title{
IMPACT OF AGRICULTURAL AGGRAVATION ON ECOLOGY
}

\author{
Narahari P. Ghimire, MSc.Ento. ${ }^{18}$
}

\begin{abstract}
There is a problem of pesticides for both the growers and consumers. Injudicious uses of pesticides also create pest problems. In addition, emissions of green house gases are creating serious ecological concern. Adoption of IPM approach, use of crop residues, mulching, fertilizer management and organic farming are some of the potential mitigating measures. It should be implemented with consensus and commitment under the guidance of appropriate policy framework.
\end{abstract}

Key words: Agriculture, ecology, IPM, policy

\section{Introduction}

Use of pesticides in agriculture has created four fold problems through different trophic levels: health related problems, environmental pollution, yield loss due to non-target pesticide application resulting in pesticide induced pest resurgence and financial burden to the poor farmers (van Emden and Peakal, 1996; Yazdani and Agrawal, 1997; van Huis, 2000). Besides the effect of pesticides, malpractice in agriculture has created other ecological problems. These all are to be managed and handled in harmony with ecological principles (Ghimire, 2001). This is possible through the decision based on agro-ecosystem analysis and appropriate policy guidelines.

\section{Objectives}

The general objective of the article is to highlight the agricultural practices based on the principles of ecology and create congenial environment for living. The specific objectives are as follows:

i. To review briefly the impact of agriculture on different aspects of the ecology,

ii. To explore the possible mitigating measures so as to keep agricultural practices in harmony with ecology, and

iii. To recommend most practical and sustainable way of farming practice.

\section{Agriculture in Relation to Ecology}

\section{Problems of Pesticides on Growers and Consumers}

Pesticide exposure creates health problems in the bodies of farm workers. Organophosphate pesticides are associated with acute health problems such as abdominal pain, dizziness, headaches, nausea, vomiting, as well as skin and eye problems. In addition, there have been many other studies that have found pesticide exposure is associated with more severe health problems such as respiratory problems, memory disorders, dermatologic conditions, cancer, depression, neurologic deficits, miscarriages, and birth defects. Summaries of peer-reviewed

\footnotetext{
${ }^{18}$ Sericulture Development Officer, Sericulture Development Section, Khopasi. Email : np2a.ghimire@gmail.com
} 
research have examined the link between pesticide exposure and neurological outcomes and cancer in organophosphate-exposed workers.

One example of this slow process is exemplified by the pesticide Dichlorvos, or DDVP, which, as recently as the year 2006, the EPA proposed its continued sale. The EPA has almost banned this pesticide on several occasions since the 1970s, but it never did so despite considerable evidence that suggests DDVP is not only carcinogenic but dangerous to the human nervous system - especially in children.

There are altogether 290 different pesticides so far registered and used in Nepal (PRMS, 2006). The pesticide import situation in Nepal is presented in Figure 1. The trend is slightly decreasing in the recent years. Quantity of active ingredients used in Nepal during 2004 and 2005 were $159341.76 \mathrm{~kg}$ and $151472.4 \mathrm{~kg}$ respectively. The difference is due to carry over of pesticides year after year.

\section{Effect of Pesticides on the Pests}

Use of pesticides and its route through different trophic levels has created four fold problems in the Nepalese society: health related problems, environmental pollution, yield loss due to non-target pesticide application resulting in pesticide induced pest resurgence and financial burden to the poor farmers and consequently the country as a whole (Thapa, 1998). More than 500 insect species have got resistance over at least one pesticide. Indiscriminate use of pesticides for controlling pests has created a chain of everlasting problems because of pest developing resistance to pesticides, pest resurgence

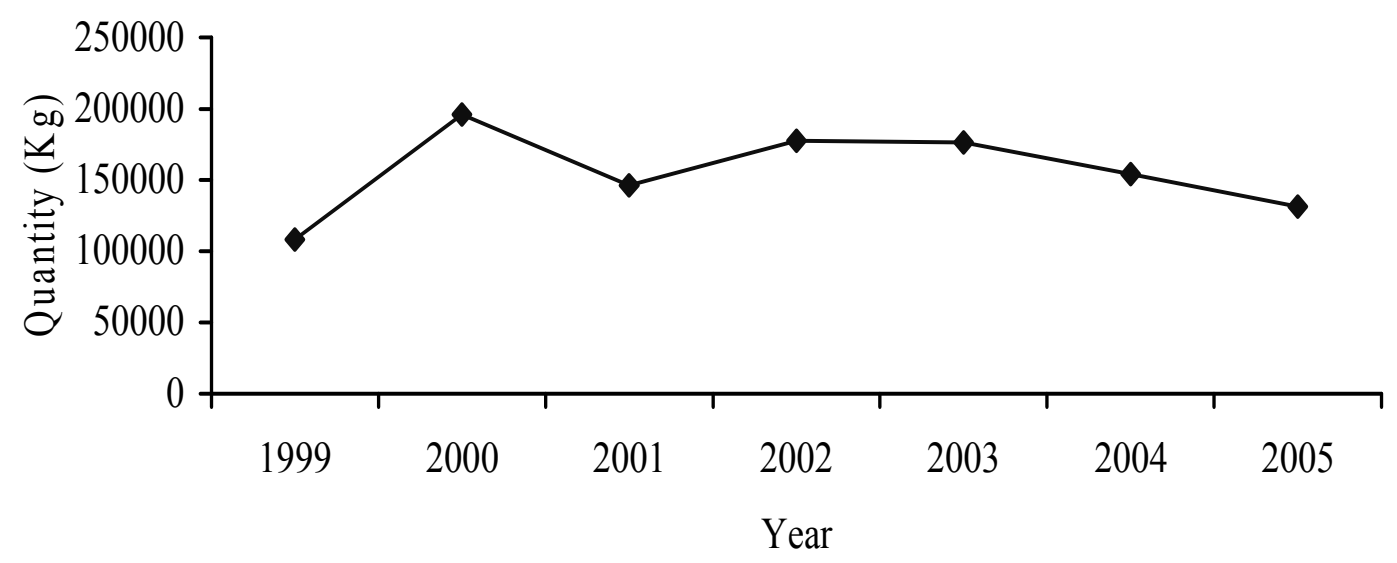

Figure 1. Pesticide import situation in Nepal

and secondary pest outbreaks. Insects do not accumulate large concentration of insecticides as they occupy second and third trophic level in food chain while top predators accumulate insecticides. Organism with short span of life of terrestrial habit have less chance of selective absorption of insecticides and its residues to the extent proving toxic to their bodies. Insects are small in size, have short life, with high populations and static feeding habit; which are when exposed to insecticides have less chance of all individuals in a population to bear the effects during their lifetime. Top predators such as birds have long span of life, feed on varieties of food, have relatively low population and hence, every individual have more chances of accumulating concentrated pesticides residues during its life. Insects have that 
inherent capacity over the top predators that they have rapid selection for behavioral and physiological resistance when exposed frequently to insecticides (Yazdani and Agrawal, 1997).

\section{The Greenhouse Gases}

The goals of less expenses and more yields per unit of land area used for production have often induced some emission of the three greenhouse gases per unit of food or fiber produced. Though there are other gases that cause ecological problems, these three greenhouse gases are of great concern. That is, during the past decade at least, less fuel has been burned and so less $\mathrm{CO}_{2}$ emitted per unit of production. Higher yields per unit area of land and conservation tillage have lessened emission of $\mathrm{CO}_{2}$ from soil organic matter. Depending upon their use in the United States, tree crops not only sequester $\mathrm{C}$, but also serve to recycle $\mathrm{C}$ as an energy crop. Improvements in animal husbandry and decreased consumption of ruminant animal products have lessened the emission of $\mathrm{CH}_{4}$. Careful application of nitrogenous fertilizer has lessened emission of $\mathrm{N}_{2} \mathrm{O}$. Additional decreases in emissions of all three greenhouse gases are possible through autonomous adaptations.

\section{Carbon Dioxide Emission and Food Grains}

Researchers led by Zhu Jianguo, a senior scientist with the Nanjing-based Institute of Soil Sciences, Chinese Academy of Sciences, studied the impacts of greenhouse gas emissions on the growth of rice and wheat crops. A technique called free-air $\mathrm{CO}_{2}$ enrichment allowed the researchers to create an artificial local atmosphere around crops growing in open fields. The protein level in rice and wheat will decrease by 10 percent by about 2050, and elements such as iron and zinc will also decline. This equates to a 50 percent increase in the current concentration of $\mathrm{CO}_{2}$ in the atmosphere. The researchers found that, under these conditions, crop yields increased by 15 percent for rice and 14 percent for wheat. The crops also grew more rapidly: 10-14 percent faster in the case of rice, and 12-20 percent faster for wheat. The scientific logic behind this is that plants take up $\mathrm{CO}_{2}$ and combine it with water to create carbohydrates that are essential for growth, so increased concentrations allow them to grow faster. But by growing faster, the rice and wheat grains accumulate less protein and other nutrients. Their study predicts that if air temperature continues to increase by $0.04^{\circ} \mathrm{C}$ each year, the amount of organic matter - derived from decaying animal and plant life - in rice fields will fall by seven per cent by 2050.

\section{Crop Residues and Mulching}

Crop residues are an important source of carbon and nutrients in agricultural systems when returned to the soil. Left on the soil surface, crop residues also serve as a mulch to decrease soil temperatures and maintain higher soil moisture and reduce $\mathrm{CO}_{2}$ emission in the atmosphere. The rate of soil organic matter decomposition is positively related to soil temperature. Mulching or using plant residues to cover the soil surface decreases extreme soil temperatures, thereby slowing decomposition, and resulting in retention of more carbon in the soil. Mulching also decreases evaporation and keeps the topsoil wetter. Incorporating organic materials as an $\mathrm{N}$ source or for other purposes generally increases $\mathrm{CH}_{4}$ emissions. If crop residues are instead burned, the benefits of return and sequestration of some of the $\mathrm{C}$ contained in these materials into soil-C pools are lost.

\section{Fertilizer Management}

Although experimental results differ, deep placement of mineral- $\mathrm{N}$ fertilizers likely decreases $\mathrm{CH}_{4}$ emissions. Fertilizer $\mathrm{N}$ is extremely important for obtaining high yields. It also decreases the ratio of $\mathrm{CH}_{4}$ produced per $\mathrm{kg}$ of rice produced. However, much more needs to be known 
to define and improve fertilizer and other cultural management practices that minimize this ratio while still providing required amounts of rice to feed the world's populations.

\section{Improved Biological Efficiency}

As the genetic potential for increased rice yield per hectare of cropland area increases, the ratio of $\mathrm{CH}_{4}$ produced per $\mathrm{kg}$ of rice should also decrease. Such improvement might also include a lower straw/grain ratio to decrease the relative amount of straw to be returned to paddy fields or burned. Increased grain yield might also help lower the land area of paddy rice required to satisfy demand, thus further decreasing $\mathrm{CH}_{4}$ emissions.

\section{Irrigation Water Management}

Generally fluxes of denitrification gases occur immediately following irrigation. Because $\mathrm{N}_{2} \mathrm{O}$ may be further changed to $\mathrm{N}_{2}$ during transport to the soil surface, especially when $\mathrm{O}_{2}$ is more limiting, there is greater opportunity to decrease the $\mathrm{N}_{2} \mathrm{O} / \mathrm{N}_{2}$ ratio of the resulting gases when the mineral $\mathrm{N}$ that is being denitrified is deeper in the soil. An effect of infrequent, compared to more frequent irrigation, is to not only decrease the number of resulting denitrification cycles, but to also help move soluble $\mathrm{N}$ deeper into the soil profile where supplies $\mathrm{O}_{2} \mathrm{O}_{2}$ are more limited and therefore there is increased opportunity to reduce any $\mathrm{N}_{2} \mathrm{O}$ that may form to $\mathrm{N}_{2}$. Very frequent irrigations tend to result in the largest amount of denitrification, whereas infrequent irrigation may increase leaching losses. Therefore, a balance would need to be drawn between the two types of $\mathrm{N}$-losses.

\section{The Mitigating Measures}

There are some mitigating measures for correcting the ecological imbalance. Integrated pest management supported with organic farming is thought to be more effective in this regard.

\section{Integrated Pest Management (IPM)}

It is estimated that Nepal looses around $20-35 \%$ of its crop due to pests. Judicious and discreet use of pesticide by the Nepalese farmer is largely ignored. The ecological implications of such careless and repeated use of all types of pesticides in the commercial areas not only inflict direct injury to wild life and beneficial insects but also imbalance the ecological harmony. A much larger emphasis is today placed on a judicious and safety in use of pesticides at all levels to keep any adverse effects to the minimum. IPM concept is finding increasing eco-friendly means of dealing with pests. IPM has been widely accepted as the alternative to pesticide application. The most important aspect is to properly educate the technician/expert/scientist and the personnel of IPM who carry these technologies to the farmers so that the methods don't go for demonstration only but validation on the large scale. Taking this into consideration, IPM and indigenous technology/traditional method of pest control should be promoted at national and regional level.

Community IPM had already finished its 3 years duration. Norwegian IPM project is now in operation. Global IPM Project has also been approved while some projects like European Union IPM Project, Regional IPM Project, SAARC IPM and Norwegian IPM Project II Phase are in pipe line (PPD, 2006).

\section{Organic Farming}

Soil organic matter is primarily rich in carbon which increases soil OM levels is directly correlated with carbon sequestration. While conventional modern farming typically depletes soil OM, organic farming builds it through the use of composted animal manures and cover crops. Organic farming practices can be used to help curb greenhouse gases. Over 23 years, there's been a 15 to $28 \%$ increase in soil carbon in organic systems, with virtually no increase in non- 
organic systems. Organic farms do not release synthetic pesticides into the environment-some of which have the potential to harm local wildlife. These farms are better than conventional farms at sustaining diverse ecosystems, i.e., populations of plants and insects, as well as animals. When calculated either per unit area or per unit of yield, organic farms use less energy and produce less waste, e.g., waste such as packaging materials for chemicals.

\section{Improvement of Farm Yard Manure (FYM)}

Farm yard manure (FYM) can be improved and made nutrient rich. FYM can be protected from direct sunlight with the help of shed over it. The FYM can be incorporated with other organic materials and piled up in a convenient place so that it can be turned up time to time easily. Use of cattle manure, lime, effective microorganism (EM) etc. in the FYM may decompose the contents quickly and quality FYM can be achieved. Biogas slurry can also be used to improve the FYM. Biogas slurry can be used solely or alternatively with cattle urine in the preparation of quality FYM.

\section{Use of Biogas Slurry}

Well digested biogas slurry alone could increase the crop production by 20 to 30 percent besides having a beneficial effect on soil conditions. In general, the vegetables responsive to biogas slurry are potatoes, tomatoes, sweet potatoes, water-melons, radishes, carrots, cauliflowers, turnips, onions, garlic etc. Fruit trees and vines such as orange, grape, apple, guava, mango etc. are also responsive to this fertilizer. Rice, sugarcane and jute respond well to biogas slurry. But wheat, barley, oats, groundnuts, linseed, sesame, castor, beans, coconut and cotton are considered to be less responsive (Bhattarai, 1978; Bhattarai and Maskey, 1978). The important benefit of biogas, in broader sense, is the conservation of environment due to saving of the forest. There has been net saving of fuel wood $(5.5 \mathrm{~kg} / \mathrm{person} / \mathrm{day}$ in the Terai and $6.6 \mathrm{~kg}$ in the hills). The saving of forest improves the environment by checking natural calamities such as soil erosion, floods, land slides, etc.

\section{Vermi-composting}

The manure is produced from the household organic matter by using earthworms. It is of high quality manure and has manifold advantages over chemical fertilizers. The organic garbage which occupies around $60 \%$ of total waste can be utilized for vermin-composting which can fetch good money by selling vermin-compost. The technology is also known as vermi-culture. There are about 4000 species of earthworms, out of them; some of the species of earthworms are used worldwide for waste degradation. The earthworm Eisenea foetida is the most suitable species for the use of vermi-composting. The species of Lampito mauritii is higher feeding habit and only short period required for composting. Eudrillus enginae has higher growth rate than Perionyx exavatus. There are other species of earthworms also but Eisenia foetida has very good efficiency with high fertility rates. Those that are found in soil in native condition are not suitable for vermi-composting as it eats only soil not organic matter.

\section{Policy Strategy and Legal Framework}

There are some legislative enactments (Annex Table 1) which are directly or indirectly related to the ecology, but the irony is that not a single legislative enactment deals with ecomanagement in its entirety. Most of the Acts are use-oriented rather than resource-oriented (Shrestha, 1999).

Nepal has become a signatory to a number of treaties related to the protection of biodiversity, habitat and national heritage. The main four treaties are: 
1. Convention on Wetlands of International Importance Especially as Waterfowl Habitat (Ramsar Convention): Nepal acceded on April 1988

2. UNESCO Convention Concerning the Protection of the World Cultural and Natural Heritage (World Heritage Convention - entered into force on 17 December 1973)

3. Convention on the International Trade in Endangered Species of Wild Fauna and Flora (CITES-entered into force on 1 July 1975) Nepal became contracting party on 18 June 1975

4. Convention on Biological Diversity (entered into force in December 1993): Nepal ratified in September 1993

Different countries of the world are directly and indirectly related with the ozone layer depletion and green house effect. Nepal has ratified the Vienna Convention, Montreal Protocol and Convention on Climate Change in early 1994.

There are some treaties to which Nepal is a party, together with an account of the obligations under the treaty and the incorporation, if any, of their provisions in Nepalese Legislation are:

1. Plant Protection Agreement for the South East Asia and Pacific Region: 12 August 1965

2. Geneva Convention on High Seas: 27 January 1963

3. Treaty Banning Nuclear Weapons Tests in the Atmosphere, in Outer Space and Under Water: 7 October 1964

4. Treaty on Principles Governing the Activities of States in the Exploration and Use of Outer Space Including the Moon and Other Celestial Bodies: 10 October 1967

5. Treaty on the Non-proliferation of Nuclear Weapons: 3 February 1970

6. Treaty on the Prohibition of the Emplacement of Nuclear Weapons of Mass Destruction on the Seabed and Ocean Floor and the Subsoil Thereof: 18 May 1972

7. International Tropical Timber Agreement: 3 July 1990

8. Bangkok Agreement on the Network of Aquaculture Centers in Asia and the Pacific: 4 January 1990

9. Convention on the Control of Transboundary Movement of Hazardous Wastes and Their Disposal, (Basel Convention): Nepal ratified in 1994

10. Convention on Combating on Desertification in those Countries Experiencing Serious Drought and/or Desertification, particularly in Africa: Nepal ratified in 1994

Nepal has yet to establish any major environmental accords and to improve the cooperation on transboundary environmental problems with its neighbors, despite the fact that ecological processes in the Himalaya clearly transcend international boundaries (Tuladhar, 1999). There are a number of steps that need to be taken at the national level for a treaty to become binding on the signatory for implementation.

\section{Conclusion and Recommendation}

Use of pesticides in agriculture has created four fold problems through different trophic levels in the Nepalese society: health related problems, environmental pollution, yield loss due to non-target pesticide application resulting in pesticide induced pest resurgence and financial burden to the poor farmers. Besides the effect of pesticides, malpractice in agriculture has created other ecological problems. These all are to be managed and handled in harmony with ecological principles. This is possible through the decision based on agroecosystem analysis and appropriate policy guidelines. 
Following are some recommendations for most practical and sustainable way of farming:

1. A national inventory should be prepared and database created on the status of pests and diseases.

2. Pest risk analysis should be conducted in the potential production areas.

3. Pest free area and organic farming area should be declared.

4. Farmers should be educated on the hazardous effects of pesticides on the human health and ecology.

5. Knowledge of farming practice should be assessed for the impact of the biotic and abiotic production inputs to sustainable production systems.

6. Farmers field school could be the appropriate approach in which farmers decide each and every steps based on agro-ecosystem analysis through discussion. They test themselves the fertilizer management, effectiveness of botanical pesticides and other practical problems.

7. Chemical pesticides should be replaced by botanicals and bio-pesticides, preferably the local origion.

8. Indiscriminate and injudicious use of pesticides should be discouraged.

9. System of rice cultivation should be shifted from conventional to system of rice intensification (SRI) that require very less amount of water than the conventional system.

10. Use gravitational water for irrigation as far as practicable thereby saving energy and protect the ground water from lowering.

11. Crop residues and other organic wastes should be either mulched or incorporated into the soil so as to increase the organic matter content in the soil.

12. Organic farming should be practiced more preferably using local resources.

13. Improvement in farm yard manure, vermi-composting, use of biogas slurry, use of EM in composting etc. are to be incorporated in the organic farming processes.

14. Local resources and indigenous technology should be identified and mobilized to make the farming system sustainable with long term integration.

15. Policy to mobilize active community participation in ecology conscious design and implementation.

16. Policy to ensure coordination, integration mechanisms and exchange of technology transfer at local, national, regional and international level should be developed.

17. A proponent should have to carry out Initial Environmental Examination (IEE) for smaller scale projects and Environment Impact Assessment (EIA) for larger projects with easier and efficient approval mechanisms from concerned authority.

Annex

Table 1. Some of the relevant acts and regulations with ecological aspects

\begin{tabular}{|l|l|l|}
\hline S.N. & Act/regulation/policy & Ecological concern \\
\hline 1 & The Town Development Act 1988 & Art. 9 \\
\hline 2 & The Civil Aviation Act 2015 (1958) & Art. 3 (2) \\
\hline 3 & Labour Act 1991 & Art. 27 \\
\hline 4 & The Aquatic Animals Protection Act 2017 (1961) & Art. 3 \\
\hline
\end{tabular}




\begin{tabular}{|l|l|l|}
\hline 5 & Public Roads Act 1974 & Art. 16 \\
\hline 6 & Mines and Minerals Act 1985 & General consideration \\
\hline 7 & $\begin{array}{l}\text { The Urban Construction Plan Implementation Act 2019 } \\
(1972)\end{array}$ & General consideration \\
\hline 8 & King Mahendra Trust for Nature Conservation Act 1982 & General consideration \\
\hline 9 & The Tourism Act 2035 (1978) & Art. 30 \\
\hline 10 & $\begin{array}{l}\text { The Soil Conservation and Watershed Management Act } \\
2039(1982)\end{array}$ & Strong consideration \\
\hline 11 & The Pesticide Act 1991 & Strong consideration \\
\hline 12 & Pesticide Regulation 1992 & Strong consideration \\
\hline 13 & Seed Act, 2045 & Strong consideration \\
\hline 14 & Plant Protection Act, 2063 & Strong consideration \\
\hline 15 & The Solid Waste Act 2044 (1986) & Chapter 3, 4 and 5 \\
\hline 16 & Nepal Water Supply Corporation Act 2046 (1989) & $\begin{array}{l}\text { Art. 5.1.10, 18.1.2 and } \\
19.2 .1\end{array}$ \\
\hline 17 & Municipality Act 2048 (1991) & Art. 15 \\
\hline 18 & District Development Committee Act 1991 & Art. 18(1) and 39 (2) \\
\hline 19 & Village Development Committee Act 1991 & Art. 14 \\
\hline 20 & The Industrial Enterprises Act 2049 (1992) & Art. 9 \\
\hline 21 & The Water Resources Act 2049 (1992) & Art. 19 and 20 \\
\hline 22 & The Forest Act 2049 (1992) & Strong consideration \\
\hline 23 & The National Parks and Wildlife Conservation Act 2030 & Strong consideration \\
(1973) & $\begin{array}{l}\text { The Vehicle and Transport Management Act 2049 } \\
\text { (1992) }\end{array}$ & Art. 24 \\
\hline 24 & Holistic approach \\
\hline 25 & The Environment Protection Act 1996 & Holistic approach \\
\hline 26 & Environment Protection Regulation 1997 & Strong consideration \\
\hline 27 & Agriculture Policy, 2061 & Strong consideration \\
\hline 28 & Bio-Technology Policy, 2005 & Strong consideration \\
\hline 29 & Agribusiness Promotion Policy, 2064 & \\
\hline & & \\
\hline
\end{tabular}

\section{REFERENCES}

1. Bhattarai, S. and S. L. Maskey, 1988, Effect of Azotobacter Inoculation in combination with different sources of organic manure. Proceeding, National Conference on Science and Technology, Khumaltar, Lalitpur, Nepal, April 24-29, 1988 pp 81-85.

2. Bhattarai, S., 1978, Report on the observation on Effect of Effluent of Gobar gas Plant on the yield of wheat under irrigated and rainfed condition. Contribution from Soil Science Division for the winter crop seminar, Aug.14-17, 1978.

3. Ghimire, N.P., 2001, Bio-magnification: a threat for ecological harmony. Paper presented at the "Eighth National Permaculture Convergence", held on 4th September 2001, at Nepalgunj, Nepal.

4. Pesticide Registration and Management Section (PRMS), 2006, Introduction, achievement and pesticide management directory of pesticide registration and management program. Pesticide Registration and Management Section, Harihar Bhawan, Lalitpur. 
5. Plant Protection Directorate (PPD), 2006, Introduction, achievement and methodology of plant protection program. Plant Protection Directorate, Harihar Bhawan, Lalitpur.

6. Shrestha, Varun Prasad, 1999, "Existing environmental policies and institutional structures overview of the national and regional environment and development issues". In Ministry of Population and Environment published, Environmental Law and Management, Report of the National Workshop on Environmental Law and Management held on March 30-April 2, 1999 at Kathmandu, Nepal. pp. 42-57.

7. Thapa, R.B., 1998, "An Overview of Pesticide Pollution in Nepal”, Nepalese J. of Hort. 1:31-39.

8. Tuladhar, Ashok Ratna, 1999, "Basel convention on the control of transboundary movements of hazardous wastes and their disposal". In Ministry of Population and Environment published, Environmental Law and Management, Report of the National Workshop on Environmental Law and Management held on March 30-April 2, 1999 at Kathmandu, Nepal. pp. 163-198.

9. Van Emden, H.F. and D.B. Peakal, 1996, Beyond Silent Spring: Integrated Pest Management and Chemical Safety, UNEP, icipe, Chapman and Hall.

10. Van Huis, A., 2000, "Pesticide-induced Outbreak of Pests: A Review", International Course on Vegetable Production 2000, Wageningen, The Netherlands. pp. 51.

11. Yazdani, S.S. and M.L. Agrawal, 1997, Elements of Insect Ecology, Narosa Publishing House. 